$\begin{array}{ll}\text { Volume } & : 05 \\ \text { Nomor } & : 03 \\ \text { Bulan } & : \text { September } \\ \text { Tahun } & : 2019 \\ \text { http } & : / / \text { ejurnal.pps.ung.ac.id/index.php/AKSARA/index }\end{array}$

\title{
PENERAPAN MODEL PEMBELAJARAN KONTEKSTUAL DALAM UPAYA MENINGKATKAN HASIL DI KABUPATEN MUNA
}

\author{
La Ode Roda \\ SD Negeri 4 Tongkuno Muna \\ Email: laoderoda@gmail.com
}

Received: 02 Juni 2019; Revised: 19 Juli 2019; Accepted: 25 Agustus 2019

\begin{abstract}
ABSTRAK
Penelitian ini di latar belakangi Model pembelajaran konvensional diduga merupakan salah satu penyebab rendahnya hasil belajar IPS siswa kelas VI SD Negeri 4 Tongkuno Kecamatan Tongkuno Kabupaten Muna. Hasil observasi menunjukkan bahwa siswa cenderung bersikap pasif karena selama pembelajaran berlangsung interaksi guru dan siswa sangat kurang. Berdasarkan latar belakang di atas, maka rumusan masalah dalam penelitian ini adalah "apakah penerapan model pembelajaran kontekstual dapat meningkatkan hasil belajar IPS siswa kelas VI SD Negeri 4 Tongkuno Kecamatan Tongkuno Kabupaten Muna?” Penelitian ini bertujuan untuk meningkatkan hasil belajar IPS siswa melalui penerapan model pembelajaran kontekstual kelas VI SD Negeri 4 Tongkuno Kecamatan Tongkuno Kabupaten Muna. Penelitian ini dilaksanakan di SD Negeri 4 Tongkuno yang terletak di kecamatan Tongkuno Kabupaten Muna, pada semester genap tahun pelajaran 2014/2015. Subyek penelitian ini adalah siswasiswi kelas VI dengan jumlah siswa sebanyak 21 orang terdiri dari 11 orang laki-laki dan 10 orang perempuan. Hasil penelitian menujukan Penerapan model pembelajaran kontekstual dapat meningkatkan aktivitas belajar siswa pada mata pelajaran IPS materi pokok Gejala Alam Di Indonesia di SD Negeri 4 Tongkuno . Persentase ketuntasan aktivitas belajar siswa pada siklus I sebesar 70,83\% dan siklus II sebesar 95,83\%. Hal ini menunjukkan terjadi peningkatan pada siklus II sebesar $25 \%$ dari siklus I dan telah mencapai indikator kinerja yang telah ditetapkan.
\end{abstract}

Kata Kunci: Penerapan Model Pembelajaran Kontekstual, PTK, Hasil Belajar Siswa.

\section{PENDAHULUAN}

Ilmu Pengetahuan Sosial adalah salah satu mata pelajaran yang wajib diberikan di SD. Kajian IPS meliputi dua kajian pokok yaitu pengetahuan sosial dan sejarah. Kajian pengetahuan sosial meliputi lingkungan sosial, ilmu bumi, ekonomi, dan pemerintahan.

Sedangkan kajian sejarah meliputi perkembangan masyarakat Indonesia sejak lampau hingga sekarang. Kenyataanya, sekarang pelajaran ilmu pengetahuan sosial seolah-olah hanya bersifat pengetahuan saja, sehingga asing bagi kehidupan sehari-hari, guru jarang mengaitkan pengetahuan yang dipelajari dihubungkan dengan fenomena sehari-hari. Di samping itu guru dalam mengajarkan suatu topik IPS, mereka kurang paham apa manfaat siswa belajar topik IPS tersebut bagi kehidupan anak.

Banyak faktor penyebab sehingga siswa tidak memahami dengan baik materi IPS yang diajarkan guru. Salah satu faktor penyebabnya adalah model pembelajaran yang digunakan guru dalam menyajikan materi. Penggunaan satu jenis model pembelajaran tertentu untuk mengajarkan suatu pokok bahasan dalam suatu pelajaran dapat menyebabkan siswa jenuh sehingga tidak tertarik lagi mengikuti pembelajaran tersebut.

Sejalan dengan uraian di atas, terlihat bahwa upaya peningkatan mutu pendidikan sangat efektif jika diarahkan pada obyek siswa yang belajar yaitu penataan proses belajar siswa, model dan tehnik belajar guru dengan asumsi bahwa untuk meningkatkan mutu pendidikan, proses 


$\begin{array}{ll}\text { Volume } & : 05 \\ \text { Nomor } & : 03 \\ \text { Bulan } & : \text { September } \\ \text { Tahun } & : 2019 \\ \text { http } & : / / \text { jurnal.pps.ung.ac.id/index.php/AKSARA/index }\end{array}$

belajar siswa, model dan tehnik mengajar guru harus dibenahi secara seksama dalam hal ini adalah proses pembelajaran. Dalam proses pembelajaran, kebanyakan siswa mengalami kesulitan dalam mengaplikasikan ke dalam situasi kehidupan nyata. Hal ini yang menyebabkan siswa merasa sulit belajar karena pembelajaran yang kurang bermakna, bila anak belajar terpisah dari pengalaman anak sehari-hari maka anak akan cepat lupa dan tidak dapat mengaplikasikannya.

Berdasarkan hasil belajar siswa pada materi pokok Persiapan Kemerdekaan Indonesia pada tahun ajaran 2014/2015 diketahui dari 15 orang siswa kelas VI hanya sebanyak 9 siswa atau $60 \%$ yang memiliki nilai $\geq 65$ dengan nilai rata-rata 62,31 . Ini belum memenuhi Kriteria Kelulusan Minimal (KKM) yang telah ditetapkan oleh SD Negeri 4 Tongkuno Kecamatan Tongkuno Kabupaten Muna yaitu $75 \%$ dari jumlah siswa memiliki nilai $\geq 65$ secara perorangan.

Hasil observasi menunjukan bahwa model pembelajaran yang digunakan guru adalah model pembelajaran konvensional yaitu model pembelajaran yang terpusat pada guru. Dengan model pembelajaran konvensional siswa kurang diberi kesempatan untuk berdiskusi dalam menjawab suatu permasalahan sehingga kreativitas siswa kurang berkembang karena tidak terbisa untuk berkerja sama dalam menyelesaikan permasalahan.

Model pembelajaran konvensional diduga merupakan salah satu penyebab rendahnya hasil belajar IPS siswa kelas VI SD Negeri 4 Tongkuno Kecamatan Tongkuno Kabupaten Muna. Hasil observasi menunjukkan bahwa siswa cenderung bersikap pasif karena selama pembelajaran berlangsung interaksi guru dan siswa sangat kurang.

Untuk mengatasi masalah tersebut, maka perlu melakukan perbaikan pembelajaran dengan menerapkan salah satu model pembelajaran yaitu model pembelajaran kontekstual di mana model pembelajaran ini merupakan model pembelajaran yang sifatnya membantu guru untuk menghubungkan mata pelajaran dengan situasi dunia nyata dan siswa diberi kesempatan untuk berdiskusi dalam menjawab permasalahan yang diajarkan sehingga kreativitas siswa dapat berkembang dan dapat terbiasa untuk bekerja sama dalam menyelesaikan masalah. Oleh karena itu, perlu dilakukan penelitian dalam upaya meningkatkan hasil belajar siswa pada mata pelajaran ilmu pengetahuan sosial (IPS) kelas VI SD Negeri 4 Tongkuno Kecamatan Tongkuno Kabupaten Muna melalui penerapan model pembelajaran kontekstual.

\section{KAJIAN PUSTAKA}

\section{Teori Belajar dan Pembelajaran}

Inti dari kegiatan pendidikan adalah suatu proses belajar, karena dengan belajar tujuan pendidikan akan tercapai. Oleh karena itu kegiatan belajar sangat penting karena berhasil tidaknya seseorang untuk menempuh pendidikan sangat ditentukan oleh baik tidaknya kegiatan belajarnya. Melalui proses belajar seseorang dapat mengembangkan potensi yang dimilikinya maupun yang ada pada lingkungannya guna meningkatkan taraf hidupnya.

Gredler dalam Angkowo (2007:47) menyatakan bahwa belajar adalah suatu perubahan yang telatif dan permanen dari suatu kecenderungan. Selanjutnya Winkel dalam Angkowo (2007:48) menyatakan bahwa belajar adalah suatu aktivitas mental/psikis yang berlangsung dalam interaksi dengan lingkungannya yang menghasilkan pengetahuan, keterampilan, nilai, sikap dan perubahan yang bersifat relatif konstan dan berbekas.

Slameto (2007:2) menyatakan bahwa belajar adalah suatu proses usaha yang dilakukan seseorang untuk memperoleh suatu perubahan tingkah laku yang baru secara keseluruhan sebagai hasil pengalamannya sendiri dalam interaksi dengan lingkungannya. Belajar dapat diartikan sebagai perubahan tingkah laku individu melalui interaksi dengan lingkungannya. 


$\begin{array}{ll}\text { Volume } & : 05 \\ \text { Nomor } & : 03 \\ \text { Bulan } & : \text { September } \\ \text { Tahun } & : 2019 \\ \text { http } & : / / \text { ejurnal.pps.ung.ac.id/index.php/AKSARA/index }\end{array}$

Dari pengertian belajar di atas dapat disimpulkan bahwa pada dasarnya belajar adalah suatu proses perubahan tingkah laku yang mengakibatkan bertambahnya pengetahuan, keterampilan, nilai dan sikap yang diperoleh dari interaksi individu dengan lingkungannya.

Konsep pembelajaran dalam dunia pendidikan dewasa ini terus berkembang seiring dengan tuntutan kemajuan ilmu pengetahuan dan teknologi. Pemahaman istilah "pembelajaran" tidak terbatas pada kegiatan guru mengajar atau membelajarkan siswa di kelas, tetapi telah digunakan untuk kegiatan pembelajaran yang spesifik, misalnya pembelajaran berbasis kompetensi, pembelajaran kontekstual, pembelajaran terpadu, pembelajaran tematik, pembelajaran konvensional, pembelajaran konstuktivis, dan sebagainya.

Pembelajaran merupakan aspek kegiatan manusia yang kompleks, yang tidak sepenuhnya dapat dijelaskan. Pembelajaran secara simple dapat diartikan sebagai produk interaksi berkelanjutan antara pengembangan dan pengalaman hidup. Dalam makna yang lebih kompleks, pembelajaran hakikatnya adalah usaha sadar dari seorang guru untuk membelajarkan siswanya (mengarahkan interaksi siswa dengan sumber belajar lainnya) dalam rangka mencapai tujuan yang diharapkan (Trianto, 2007: 17).

Winkel dalam Slameto (2007:6) mengatakan bahwa pembelajaran merupakan seperangkat tindakan yang dirancang untuk mendukukng proses belajar peserta didik, dengan memperhitungkan kejadian-kejadian eksternal yang berperan terhadap rangkaian kejadiankejadian internal yang berlangsung di dalam diri peserta didik. Lebih lanjut dijelaskan bahwa pengaturan peristiwa pembelajaran dilakukan secara saksama dengan maksud agar terjadi belajar yang berhasil guna. Pembelajaran perlu dirancang, ditetapkan tujuannya sebelum dilaksanakan, dan dikendalikan pelaksanaannya.

Menurut Soemosasmito dalam Trianto (2009:20) suatu pembelajran dikatakan efektif apabila memenuhi persyaratan utama keefektifan pengajaran, yaitu:

1) Presentasi waktu belajar siswa yang tinggi dicurahkan terhadap KBM;

2) Rata-rata perilaku melaksanakan tugas yang tinggi diantara siswa;

3) Ketetapan antara kandungan materi ajaran dengan kemampuan siswa (orientasi keberhasilan belajar) diutamakan; dan

4) Mengembangkan suasana belajar yang akrab dan positif, mengembangkan struktur kelas yang mendukung butir (2), tanpa mengabaikan butir (4).

Dari makna ini jelas terlihat bahwa pembelajaran merupakan interaksi dua arah dari seorang guru dan peserta didik, antara keduanya terjadi komunikasi (transfer) yang intens dan terarah menuju pada suatu target yang telah ditetapkan sebelumnya.

\section{Konsep Dasar Model Pembelajaran Kontekstual}

Pembelajaran kontekstual adalah suatu strategi pembelajaran yang menekankan pada proses keterlibatan siswa secara penuh untuk dapat menemukan materi yang dipelajari dan menghubungkannya dengan situasi kehidupan nyata sehingga mendorong siswa untuk dapat menerapkannya dalam kehidupan mereka (Sanjaya, 2006: 255).

Pembelajaran kontekstual merupakan konsep dasar yang membantu guru mengaitkan antara materi yang diajarkan dengan situasi dunia nyata siswa dan mendorong siswa untuk membuat hubungan antara pengetahuan yang dimiliki dengan penerapannya dalam kehidupan mereka sebagai anggota kelurga dan masyarakat. Dengan konsep itu hasil pembelajaran diharapkan lebih bermakna bagi siswa. Proses pembelajaran berlangsung alamiah dalam bentuk kegiatan siswa. Siswa belajar dan mengalami transfer ilmu dari guru dan ke siswa. Strategi pembelajaran lebih dipentingkan dari pada hasil. 


$\begin{array}{ll}\text { Volume } & : 05 \\ \text { Nomor } & : 03 \\ \text { Bulan } & : \text { September } \\ \text { Tahun } & : 2019 \\ \text { http } & : / / \text { ejurnal.pps.ung.ac.id/index.php/AKSARA/index }\end{array}$

Menurut Sanjaya (2006:268), pembelajaran kontekstual memiliki 7 azas yaitu :

1. Konstruktivisme (Constructivisme)

Kontruktivisme adalah merupakan membangun atau menyusun pengetahuan baru dalam struktur kognitif siswa berdasarkan pengalaman.

2. Menemukan (inkuiri)

Bahwa proses pembelajaran didasarkan pada pencarian dan penemuan melalui proses berpikir secara sistematis.

3. Bertanya (questioning)

Bertanya dapat dipandang sebagai refleksi dari keingintahuan setiap individu. Dalam pembelajaran kontekstual, guru tidak menyampaikan informasi begitu saja akan tetapi memancing siswa agar dapat menemukan sendiri. Karena itu peran bertanya sangat penting.

4. Masyarakat Belajar (Learning Community)

Masyarakat belajar dapat dilakukan dengan menerapkan pembelajaran melalui kelompok belajar. Siswa dibagi dalam beberapa kelompok yang anggotanya bersifat heterogen, baik dilihat dari kemampuan maupun bakat dan minatnya.

5. Pemodelan (Modeling)

Pemodelan merupakan proses pembelajaran dengan memperagakan sesuatu sebagai contoh yang dapat ditiru oleh setiap siswa misalnya bagaimana cara menggunakan thermometer dan lain sebagainya.

6. Refleksi (Reflection)

Refleksi adalah proses pengendapan pengalaman yang telah dipelajari yang dilakukan dengan cara mengurutkan kembali kejadian-kejadian atau peristiwa pembelajaran yang telah dilaluinya. Melalui proses refleksi, pengalaman belajar itu akan dimasukan ke dalam struktur kognitif siswa yang pada akhirnya akan menjadi bagian dari pengetahuan yang dimilikinya.

7. Penilaian yang sebenarnya (Authentic Assesment)

Assesment adalah proses yang dilakukan oleh guru untuk mengumpulkan informasi tentang perkembangan belajar yang dilakukan oleh siswa. Penilaian dilakukan secara terus menerus selama kegiatan pembelajaran berlangsung.

\section{Karakteristik dan Prinsip Model Pembelajaran Kontekstual}

Menurut Syaefudin (2009:162-164) terdapat lima karakteristik penting dalam proses pembelajaran yang menggunakan model pembelajaran kontekstual seperti:

1. Pembelajaran merupakan proses pengaktifan pengetahuan yang sudah ada (activtinging knowledge), artinya apa yang akan dipelajari tidak terlepas dari pengetahuan yang sudah dipelajari, dengan demikian pengetahuan yang akan diperoleh siswa adalah pengetahuan yang memiliki keterkaitan antara yang satu dengan yamg lainnya.

2. Pembelajaran kontekstual adalah belajar dalam rangka memperoleh dan menambah pengetahuan baru (acquiring knowledge). Pengetahuan baru itu diperoleh dengan cara deduktif, artinya pembelajaran dimulai dengan mempelajari secara keseluruhan, kemudian memperhatikan detailnya.

3. Pemahaman pengetahuan (understanding knowledge), artinya pengetahuan yang diperoleh bukan untuk dihafal tapi untuk dipahami dan diyakini, misalnya dengan cara meminta tanggapan dari yang lain Pemahaman pengetahuan (understanding knowledge), artinya pengetahuan yang diperoleh bukan untuk dihafal tapi untuk dipahami dan diyakini, misalnya dengan cara meminta tanggapan dari yang lain tentang pengetahuan yang diperolehnya dan berdasarkan tanggapan tersebut. 


$\begin{array}{ll}\text { Volume } & : 05 \\ \text { Nomor } & : 03 \\ \text { Bulan } & : \text { September } \\ \text { Tahun } & : 2019 \\ \text { http } & : / / \text { jurnal.pps.ung.ac.id/index.php/AKSARA/index }\end{array}$

4. Mempraktikkan pengetahuan dan pengalaman tersebut (applying knowledge) artinya pengetahuan dan pengalaman yang diperolehnya harus dapat diaplikasikan dalam kehidupan siswa, sehingga tampak perubahan tingkah laku yang diperolehnya dari pengetahuan.

5. Melakukan refleksi (reflecting knowledge) terhadap strategi pengembangan pengetahuan. Hal ini dilakukan sebagai umpan balik untuk proses perbaikan atau penyempurnaan strategi

Elaine B. Jhonson dalam Syaefudin (2009:165-167) mengatakan bahwa dalam model pembelajaran kontekstual, minimal ada tiga prinsip utama yang sering digunakan yaitu sebagai berikut:

1) Prinsip saling ketergantungan, menurut hasil kajian para ilmuan segala yang ada di dunia ini adalah saling berhubungan dan tergantung. Begitu pula dala pendidikan dan pembelajaran, sekolah merupakan suatu sistem kehidupan, yang terkait dalam kehidupan di rumah, di tempat kerja, di masyarakat. Dalam kehidupan di sekolah siswa saling berhubungan dan tergantung pada guru, kepala sekolah, tata usaha, orang tua siswa, dan narasumber yang ada di sekitarnya.

2) Dalam proses pembelajaran siswa, berhubungan dengan media ajar, sumber belajar, media, sarana prasarana belajar, iklim sekolah dan lingkungan.

3) Prinsip diferensiasi, yang menunjukkan kepada sifat alam yang secara terus menerus menimbulkan perbedaan, keseragaman, keunikan. Diferensiasi bukan hanya menunjukkan perubahan dan kemajuan tanpa batas, akan tetapi juga kesatuan-kesatuan yang berbeda tersebut berhubungan, saling tergantung dalam keterpaduan yang bersifat simbiosis atau saling menguntungkan. Apabila para pendidik memiliki keyakinan yang sama dengan para ilmuan modern bahwa prinsip diferensiasi yang dinamis ini bukan hanya berlaku dan berpengaruh pada alam semesta, tetapi juga pada sistem pendidikan. Para pendidik juga dituntut untuk mendidik, mengajar, melatih, membimbing, sejalan dengan prinsip diferensiasi dan harmoni alam semesta ini.

\section{Teori Hasil Belajar}

Angkowo (2007:51) menyatakan bahwa ada tiga ranah (domain hasil belajar, yaitu kognitif, psikomotorik, dan afektif. Ranah kognitif merupakan aspek yang berkaitan dengan kemampuan berpikir, kemampuan memperoleh pengetahuan, pengenalan, pemahaman, konseptualisasi, penentuan dan penalaran. Ranah psikomotorik merupakan aspek yang berkaitan dengan kemampuan pekerjaan dengan melibatkan anggota badan, kemampuan yang berkaitan dengan gerak fisik. Ranah afektif, merupakan aspek yang berkaitan dengan perasaan, emosi, sikap, derajad penerimaan atau penolakan terhadap suatu objek. Jadi. hasil belajar merupakan perubahan yang diperoleh setelah terjadinya proses belajar mengajar yang dapat dinilai melalui tes setelah proses pembelajaran.

Hasil belajar dapat bersifat tetap dalam sejarah kehidupan manusia karena sepanjang kehidupannya selalu mengejar prestasi menurut bidang dan kemampuan masing-masing. Hasil belajar dapat memberikan kepuasan kepada orang yang bersangkutan, khususnya orang yang sedang menuntut ilmu di sekolah. Hasil belajar meliputi segenap ranah kejiwaan yang berubah sebagai akibat dari pengalaman dan proses belajar siswa yang bersangkutan.

Hasil belajar dapat dinilai dengan cara sebagai berikut:

a. Penilaian formatif, yaitu kegiatan penilaian yang bertujuan untuk mencari umpan balik (feedback), yang selanjutnya hasil penilaian tersebut dapat digunakan untuk memperbaiki proses belajar mengajar yang sedang atau sudah dilaksanakan. 


$\begin{array}{ll}\text { Volume } & : 05 \\ \text { Nomor } & : 03 \\ \text { Bulan } & : \text { September } \\ \text { Tahun } & : 2019 \\ \text { http } & : \text { //ejurnal.pps.ung.ac.id/index.php/AKSARA/index }\end{array}$

b. Penilaian sumatif, yaitu penilaian yang dilakukan untuk memperoleh data atau informasi sampai di mana penguasaan atau pencapaian belajar siswa terhadap bahan pelajaran yang telah dipelajarinya selama jangka waktu tertentu.

c. Dalam kegiatan pengukuran hasil belajar, siswa dihadapkan pada tugas, pertanyaan atau persoalan yang harus dipecahkan atau dijawab. Hasil pengukuran tersebut masih berupa skor mentah yang belum dapat memberikan informasi kemampuan siswa. Agar dapat memberikan informasi yang diharapkan tentang kemampuan siswa maka diadakan penilaian terhadap keseluruhan proses belajar mengajar sehingga akan memperlihatkan banyak hal yang dicapai selama proses belajar mengajar. Misalnya pencapaian aspek kognitif, afektif, dan psikomotorik. Hasil belajar menurut Bloom dalam Angkowo (2007:55) mencakup tiga aspek yaitu kognitif, afektif, psikomotorik. Dalam penelitian ini yang ditinjau adalah aspek kognitif yang meliputi pengetahuan, pemahaman, dan penerapan.

Berdasarkan penilaian yang dilaksanakan guru di sekolah, maka hasil belajar IPS siswa dituangkan atau diwujudkan dalam bentuk angka (kuantitatif) dan pernyataan verbal (kualitatif). Hasil belajar yang dituangkan dalam bentuk angka misalnya 10, 9, 8, dan seterusnya. Sedangkan hasil belajar yang dituangkan dalam bentuk pernyataan verbal misalnya, baik sekali, baik, sedang, kurang, dan sebagainya (Djuwairiyah, 2007:16).

Berdasarkan pengertian yang dikemukakan, maka hasil belajar diperoleh dari usaha belajar yang dilakukan. Hasil belajar merupakan ukuran keberhasilan usaha belajar yang dilakukan oleh siswa pada suatu mata pelajaran. Hal ini ditentukan setelah menyelesaikan suatu tes sehubungan dengan mata pelajaran yang dipelajari. Singkatnya, hasil belajar dapat dikatakan sebagai hasil akhir yang telah dicapai oleh seseorang setelah melakukan usaha belajar.

\section{METODE PENELITIAN}

Jenis penelitian ini adalah penelitian tindakan kelas (PTK), yaitu penelitian yang dimaksudkan untuk memberikan informasi bagaimana tindakan yang tepat untuk meningkatkan keaktifan siswa. Sehingga penelitian ini difokuskan pada tindakan-tindakan sebagai usaha untuk meningkatkan keaktifan siswa dalam belajar IPS.

Penelitian ini dilaksanakan di SD Negeri 4 Tongkuno yang terletak di kecamatan Tongkuno Kabupaten Muna, pada semester genap tahun pelajaran 2014/2015. Subyek penelitian ini adalah siswa-siswi kelas VI dengan jumlah siswa sebanyak 21 orang terdiri dari 11 orang laki-laki dan 10 orang perempuan.

Faktor-faktor yang diteliti dalam penelitian ini adalah sebagai berikut: Faktor siswa: untuk melihat kemampuan siswa dalam mempelajari IPS. Faktor guru: untuk melihat bagaimana teknik guru dalam menerapkan model pembelajaran kontekstual.

Prosedur penelitian tindakan kelas ini direncanakan dalam 2 siklus dan dilaksanakan sesuai dengan perubahan yang ingin dicapai seperti apa yang telah didesain dalam faktor yang diselidiki. Dari hasil observasi dan evaluasi awal maka pelaksanaan penelitian tindakan kelas ini mengikuti prosedur berikut: (1) perencanaan, (2) pelaksanaan tindakan, (3) observasi dan evaluasi, (4) refleksi.

\section{HASIL PENELITIAN DAN PEMBAHASAN}

Penelitian ini diawali dengan kegiatan observasi awal. Hasil observasi menunjukkan bahwa hasil belajar siswa pada mata pelajaran IPS masih tergolong rendah. Berdasarkan hasil belajar siswa pada materi pokok Gejala alam di Indonesia pada semester genap tahun ajaran 2014/2015 diketahui dari 21 orang siswa kelas VI sebanyak 15 siswa atau $60 \%$ yang memiliki nilai $\geq 65$ dengan nilai rata-rata 62,31. Ini belum memenuhi ketuntasan belajar yang telah ditetapkan oleh 


$\begin{array}{ll}\text { Volume } & : 05 \\ \text { Nomor } & : 03 \\ \text { Bulan } & : \text { September } \\ \text { Tahun } & : 2019 \\ \text { http } & : \text { //ejurnal.pps.ung.ac.id/index.php/AKSARA/index }\end{array}$

SD Negeri 4 Tongkuno Kecamatan TongkunoKabupaten Muna yaitu 75\% dari jumlah siswa memiliki nilai $\geq 65$ secara perorangan. Hal ini memberikan gambaran bahwa hasil belajar IPS siswa masih tergolong rendah. Selain itu dalam proses pembelajaran terlihat bahwa guru menggunakan model pembelajaran konvensional yaitu model pembelajaran yang terpusat pada guru sehingga siswa cenderung bersikap pasif karena selama pembelajaran berlangsung interaksi guru dan siswa sangat kurang.

Untuk mengatasi masalah tersebut, maka perlu dilakukan perbaikan pembelajaran dalam upaya meningkatkan hasil belajar siswa pada mata pelajaran ilmu pengetahuan sosial (IPS) kelas V SD Negeri 4 Tongkuno Kecamatan Tongkuno Kabupaten Muna melalui penerapan model pembelajaran kontekstual.

\section{Perencanaan}

Setelah ditetapkan untuk menerapkan pembelajaran dengan menggunakan model pembelajaran kontekstual dalam mengajarkan materi pokok Gejala alam di Indonesia, maka kegiatan selanjutnya adalah menyiapkan beberapa hal yang diperlukan pada saat pelaksanaan tindakan yaitu sebagai berikut:

1) Membuat rancangan perbaikan pembelajaran (RPP) untuk tindakan siklus I.

2) Menyiapkan lembar observasi yang ditujukan pada guru dan siswa (aspek yang diobservasi didasarkan pada langkah-langkah pembelajaran pada RPP).

3) Menyiapkan lembar kerja siswa (LKS).

4) Membuat alat evaluasi untuk tes tindakan siklus I.

Persiapan lainnya adalah lebih memantapkan pengetahuan dan pemahaman guru mengenai pelaksanaan pembelajaran dengan model pembelajaran kontekstual. Hasil analisis pengamatan tentang proses dan produk pembelajaran diperoleh melalui observasi. Pengamatan proses adalah pengamatan yang dilakukan selama siswa mengikuti proses pembelajaran dan guru pada proses pembelajaran, sedangkan pengamatan produk adalah hasil tes yang dikerjakan oleh siswa setelah mengikuti kegiatan pembelajaran. Pengamatan dilakukan oleh peneliti dan teman sejawat.

\section{Pelaksanaan Tindakan}

Pada tahap ini, kegiatan pembelajaran dengan menerapkan model pembelajaran kontekstual dilaksanakan sesuai dengan rancangan perbaikan pembelajaran (RPP) yang telah dipersiapkan, sebagaimana yang terdapat pada lampiran 2 dan 3. Pembelajaran di awali dengan guru menyampaikan materi dan tujuan pembelajaran. Selanjutnya, guru memberikan apersepsi dengan mengingatkan kembali materi yang telah diberikan pada pertemuan sebelumnya dan memberikan motivasi dengan tanya jawab secara singkat.

Dalam kegiatan kelompok, guru membagikan LKS kepada masing-masing kelompok dan meminta kepada tiap kelompok untuk berdiskusi dan saling membagi tugas dalam menyelesaikan soal-soal yang diberikan. Guru memantau dan memberikan bimbingan terhadap kegiatan diskusi terutama terhadap kelompok yang mengalami kesulitan dalam menyelesaikan soal-soal yang ada didalam LKS. Pada saat diskusi kelompok berlangsung, masih ada siswa yang hanya diam pada saat diskusi sehingga tidak terjalin kerjasama yang baik antara anggota kelompok.

Setelah waktu yang diberikan untuk diskusi kelompok selesai, guru meminta perwakilan dari setiap kelompok untuk mempersentasekan hasil diskusinya. Hasil persentase kelompok ini sudah menunjukkan jawaban yang benar, dan pada saat persentase tidak ada tanggapan dari kelompok lain. Guru memberikan kesempatan kepada siswa untuk menanyakan hal-hal yang 


$\begin{array}{ll}\text { Volume } & : 05 \\ \text { Nomor } & : 03 \\ \text { Bulan } & : \text { September } \\ \text { Tahun } & : 2019 \\ \text { http } & : / / \text { ejurnal.pps.ung.ac.id/index.php/AKSARA/index }\end{array}$

belum dimengerti kemudian memberikan penghargaan kepada kelompok yang diskusinya lebih baik. Selama proses pembelajaran berlangsung observer.

\section{Observasi}

Pada tahap ini peneliti mengobservasi setiap pelaksanaan proses pembelajaran selama siklus I menggunakan lembar observasi. Setiap aspek yang diamati disusun mengacu pada rencana perbaikan pembelajaran (RPP) dan ditujukan terhadap guru dan siswa kelas VI SD Negeri 4 Tongkuno . Hal-hal yang diobservasi meliputi cara guru dalam menyampaikan materi pelajaran yang sesuai dengan model pembelajaran kontekstual dan sikap siswa selama mengikuti pelajaran, keaktifan siswa selama diskusi kelompok, keberanian siswa untuk bertanya dan menyampaikan pendapat.

\section{Evaluasi}

Setelah pelaksanaan tindakan siklus I selama 2 kali pertemuan, diadakan evaluasi untuk melihat peningkatan hasil belajar siswa.

\section{Pembahasan}

Penelitian ini dilaksanakan dalam dua siklus, terdiri atas kegiatan pendahuluan yakni observasi awal untuk mengetahui kelemahan-kelemahan dalam proses pembelajaran khususnya kegiatan pembelajaran sebelum menggunakan model pembelajaran kontekstual.

Hasil observasi awal menunjukkan bahwa model pembelajaran yang digunakan guru adalah model pembelajaran konvensional yaitu model pembelajaran yang terpusat pada guru. Dengan model pembelajaran konvensional siswa kurang diberi kesempatan untuk berdiskusi dalam menjawab suatu permasalahan sehingga kreativitas siswa kurang berkembang karena tidak terbisa untuk berkerja sama dalam menyelesaikan permasalahan.

Model pembelajaran konvensional diduga merupakan salah satu penyebab rendahnya hasil belajar IPS siswa kelas VI SD Negeri 4 Tongkuno Kecamatan TongkunoKabupaten Muna. Hal ini terlihat dari hasil belajar siswa yang tergolong rendah. Dari 21 orang siswa kelas VI hanya 14 orang atau 53,33\% yang memiliki nilai $\geq 65$ dengan nilai rata-rata 65,09 . Ini belum memenuhi ketuntasan belajar yang telah ditetapkan oleh SD Negeri 4 Tongkuno Kecamatan TongkunoKabupaten Muna yaitu 75\% dari jumlah siswa memiliki nilai $\geq 65$ secara perorangan. Tentu hal ini mengharuskan perlu adanya suatu tindakan dalam pembelajaran sehingga dapat meningkatkan hasil belajar siswa di kelas tersebut.

Untuk mengatasi masalah tersebut, maka perlu melakukan perbaikan pembelajaran dengan menerapkan model pembelajaran kontekstual yaitu model pembelajaran yang sifatnya membantu guru untuk menghubungkan mata pelajaran dengan situasi dunia nyata dan memberi kesempatan kepada siswa untuk berdiskusi dalam menjawab permasalahan yang diajarkan sehingga kreativitas siswa dapat berkembang dan dapat terbiasa untuk bekerja sama dalam menyelesaikan masalah.

Setelah kegiatan pendahuluan dilakukan kemudian dilaksanakan tindakan yang terdiri atas dua siklus yakni siklus I dan siklus II. Selama pelaksanaan tindakan observer. 


$\begin{array}{ll}\text { Volume } & : 05 \\ \text { Nomor } & : 03 \\ \text { Bulan } & : \text { September } \\ \text { Tahun } & : 2019 \\ \text { http } & : / / \text { ejurnal.pps.ung.ac.id/index.php/AKSARA/index }\end{array}$

\section{PENUTUP}

Setelah pelaksanaan siklus I dan siklus II, serta hasil analisis data dan pembahasan dalam penelitian ini, dapat ditarik kesimpulan sebagai berikut: Penerapan model pembelajaran kontekstual dapat meningkatkan hasil belajar siswa kelas VI SD Negeri 4 Tongkuno pada mata pelajaran IPS materi pokok Gejala Alam di Indonesia. Persentase hasil belajar siswa pada siklus I sebesar 66,67\% dan siklus II sebesar 95,83\%. Hal ini menunjukkan terjadi peningkatan pada siklus II sebesar 29,16\% dari siklus I dan telah mencapai indikator kinerja yang telah ditetapkan.

Penerapan model pembelajaran kontekstual dapat meningkatkan aktivitas mengajar guru kelas VI SD Negeri 4 Tongkuno pada mata pelajaran IPS materi pokok Gejala Alam Di Indonesia. Persentase ketuntasan aktivitas mengajar guru pada siklus I sebesar $75 \%$ dan siklus II sebesar $100 \%$. Hal ini menunjukkan terjadi peningkatan pada siklus II sebesar $25 \%$ dari siklus I dan telah mencapai indikator kinerja yang telah ditetapkan.

Penerapan model pembelajaran kontekstual dapat meningkatkan aktivitas belajar siswa pada mata pelajaran IPS materi pokok Gejala Alam Di Indonesia di SD Negeri 4 Tongkuno. Persentase ketuntasan aktivitas belajar siswa pada siklus I sebesar 70,83\% dan siklus II sebesar $95,83 \%$. Hal ini menunjukkan terjadi peningkatan pada siklus II sebesar $25 \%$ dari siklus I dan telah mencapai indikator kinerja yang telah ditetapkan.

\section{DAFTAR PUSTAKA}

Ahiri, Jafar. 2008. Faktor-faktor yang Mempengaruhi Kemampuan siswa. Kendari: Universitas Haluoleo.

Angkowo, R. 2007. Optimalisasi Media Pembelajaran. Jakarta : PT. Grasindo.

Asmawan. 2009. Penerapan Pembelajaran Eksperimen Dalam Meningkatkan Hasil

Belajar Siswa Kelas II Mata Pelajaran IPA Di SD Negeri 1 Abeli. Kendari: Universitas Haluoleo.

Djuwairiyah. 2007. Penerapan Metode Belajar Aktif Sebagai Upaya Membantu Meningkatkan Prestasi Belajar Pada Siswa Kelas VI. Probolinggo : SDN Tisnonegaran 2. (Diakses tanggal 4 Maret 2009 dari: http://media.diknas.go.id).

Jumadi. 2003. Pembelajaran Eksperimen Dan Implementasinya Makalah disampaikann pada Workshop Sosialisasi dan Iplementasi Kurikulum 2004 Madrayah Aliyah. Yogyakarta: Universitas Negeri Yogyakarta

Lisna. 2009. Meningkatkan Hasil Belajar IPA siswa kelas I SD Negeri 15 Raha Kabupaten Muna. Kendari: Universitas Haluoleo.

Nursid Sumaatmadja. 1979. Metodologi Pengajaran Ilmu Pengetahuan Sosial(IPS.) Bandung: Alumni Pustaka.

Sanjaya, W. 2006. Strategi Pembelajaran Berorientasi Standar Proses Pendidikan. Perdana Media Grup. Jakarta.

Slameto, 2007. Belajar dan Faktor-Faktor yang Mempengaruhinya. Jakarta: Rineka Cipta.

Syaefudin, U. 2009. Inovasi pendidikan. Bandung: Alfabeta. 


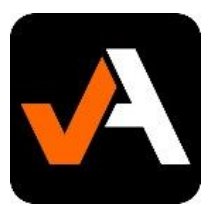

Volume : 05

Nomor : :03

Bulan : : September

Tahun : :2019

http : : //ejurnal.pps.ung.ac.id/index.php/AKSARA/index

Tim Pelatih Proyek PGSM. 1999. Penelitian Tindakan Kelas (Classroom Action Research). Balai Pelatihan Dosen LPTK dan Guru Sekolah menengah. Jakarta: Depdikbud Dikti PGSM.

Trianto. 2007. Model Pembelajaran Terpadu Dalam Teori dan Praktek. Jakarta: Prestasi Pustaka Publisher.

Wartini. 2010. Meningkatkan Hasil Belajar IPA Siswa Pada Materi Pokok Berorganisasi Kelas I di SD Negeri 1 Tapuhaka Kabupaten Bombana. Kendari: Universitas Haluoleo. 
Volume : 05

Nomor : :03

Bulan : September

Tahun : 2019

http : //ejurnal.pps.ung.ac.id/index.php/AKSARA/index 